\title{
Література
}

1. Алексеева И. С. Профессиональное становление молодых специалистов в условиях сельской школы: автореф. дис. на соискание ученой степени канд. пед. наук : спец. : 13.00.01 - «Общая педагогика, история педагогики и образования» / Ирина Степановна Алексеева. - Якутск, 2006. - 21 с. 2. Анцыферова Л. И. Психология личности как развивающейся системы / Л. И. Анцыферова // Психология формирования и развития личности. - М. : Наука, 1991. - 238 с. 3. Закон України «Про освіту» від 23 травня 1991 року. [Електронний ресурс]. - Режим доступу: osvita.ua. 4. Національна доктрина розвитку освіти України у XXI столітті. [Електронний ресурс]. - Режим доступу: http://www.gdo.kiev.ua. 5. Маркова А. К. Психология профессионализма / А. К. Маркова - М. : Знание. - 1996. - 308 с. 6. Федотенко И. Л. Молодой учитель и его старшие коллеги: два взгляда на одну проблему // Директор школы. - 1997. - № 4. С. 18-24. 7. Федеральная целевая программа развития образования на 2011-2015 годы. [Електронний ресурс].- Режим доступу: http://www.garant.ru/products/ipo/prime/doc/ $55070647 /$.

УДК 37.036:371.13:78.01

Лариса Серих

\section{ГУМАННІ ВЗАЄМИНИ ЯК БАЗОВИЙ КОМПОНЕНТ ЗМІСТУ ФОРМУВАННЯ ЕСТЕТИЧНОГО СЕРЕДОВИЩА УЧНІВ ОСНОВНОї ТА СТАРШОЇ ШКОЛИ}

Сєрих Л. В. Гуманні взаємини як базовий компонент змісту формування естетичного середовища учнів основної та старшої школи

У статті розкрито результати експерименту відповідно до теми дослідження. Визначено ступінь здатності учнів до естетичної діяльності та ступінь розуміння естетичної цінності навколишнього світу, вияв інтересу до мистецтва, створення гуманних взаємини. Розглянуто сутність гуманних взаємовідносин учнів основної та старшої школи i показано вплив таких стосунків на формування естетичного середовища старшокласників.

Ключові слова: гуманні взаємини, естетичне середовище, вчительекспериментатор, учні основної та старшої школи, естетична діяльність.

Серых Л. В. Гуманные взаимоотношения как базовый компонент содержания формирования эстетической среды учащихся основной и старшей школы.

В статье раскрыты результаты эксперимента в соответствии темы исследования. Определена степень способности учащихся к эстетической деятельности и степень понимания эстетической ценности окружающего мира, проявление интереса к искусству, создания гуманных взаимоотношений. Рассмотрена сущность гуманных взаимоотношений учеников основной и старшей школы, показано влияние данных отношений на формирование эстетического среды старшеклассников.

Ключевые слова: гуманные взаимоотношения, эстетическая среда, учительэкспериментатор, учащиеся основной и старшей школы, эстетическая деятельность.

Sierykh L. V. Humane relationships as a basic component of the content of forming aesthetic environment of pupils primary and high school.

The article deals with the results of the experiment under the topic of the research. The degree of ability of pupils to the aesthetic activity and the degree of understanding of the aesthetic values of the surrounding world, the manifestation of interest in the art determined, 
making humanistic relationship. The essence of human relations students primary and high schools and show the impact of these relations on the formation of the aesthetic environment seniors.

Key words: humanistic relationship, aesthetic environment, the teacher-experimenter, schoolchild and high school principals, aesthetic activity.

Вимоги до виховання, як відомо, є багатоплановими, зумовлюються потребами дітей, батьків, суспільства, держави, екології, виробництва тощо. Постає питання, як їх упорядкувати. Тому має йтися про викремлення базового компонента у вихованні, насамперед морально-естетичного виховання. Моральність є своєрідним стрижнем виховного процесу, визначає його спрямованість і цілісність, у ній глибинний зміст виховання. Не виховавши моральності, неможливо забезпечити особистісні основи людської життєдіяльності. Естетичне виховання - це інтегративна цілісність, яка поєднує в собі сприймання, створення, діяльність за законами краси і гармонії. Це водночас також цілісність відтворення особистості. У процесі їі формування забезпечується єдність усіх напрямків урочної, позаурочної, позашкільної виховної роботи, створюються реальні умови для створення комфортного естетичного середовища.

Мета статmi - розглянути сутність гуманних стосунків учнів основної та старшої школи, та показати вплив таких взаємин на формування естетичного середовища старшокласників.

Формування естетичного середовища учнів основної та старшої школи засобами різних видів і жанрів мистецтва в загальноосвітніх школах, позанавчальних закладах спираються на науково-педагогічні дослідження процесів формування світоглядних позицій (К. Ушинський, А. Макаренко, В. Сухомлинський), де утверджується ідея підготовки високої духовної культурної, творчої особистості, здатної перетворювати себе і світ; коригується спрямованість навчання на формування творчої особистості, на своєрідність іiі індивідуальних виявів (В. Загвязінський, О. Кульчицька, В. Рибалка, В. Шубинський, П. Щедровицький та інші). Розв'язання в педагогіці проблеми професійного розвитку особистості неможливе без використання наукових уявлень про психологічний розвиток людини як особистості, ऑiі природних характеристик (Л. Виготський, Г. Костюк, О. Леонтьєв, С. Рубінштейн, Б. Тєплов).

Доцільність формування цілісного естетичного середовища набуває особливої значущості в сучасних соціокультурних умовах. Нині спостерігається нерозвиненість емоційно-почуттєвої сфери, низький рівень естетичної культури школярів, відсутність справжньої духовності 3 одночасним превалюванням однобічного і спрощеного ставлення до мистецтва як до розваги, що призводить до зниження моральноестетичних критеріїв особистості. У такій ситуації підвищується відповідальність педагогів за формування культуротворчого, неутилітарного характеру ціннісних орієнтирів особистості, одним із яких є естетичне виховання.

Забезпечення формування цілісного естетичного середовища учнів основної i старшої школи можна досягти різними засобами, зокрема у процесі використання естетико-виховних можливостей естетичного виховання та створення гуманних взаємовідносин старшокласників.

До проблеми формування естетичного середовища, комплексного естетичного виховання і міжжанрового зв'язку різних видів мистецтва зверталися філософи, психологи, мистецтвознавці, педагоги: Б. Асаф'єв, Т. Крижанівська, Г. Падалка, В. Разумний та ін. У працях Н. Антонової, І. Барвінок, М. Баскіна, К. Горбунової, С. Грибкова, Г. Фролової, В. Шахрай міститься наукове обгрунтування педагогічної мети, завдання і змісту художньо-творчої діяльності. Як свідчать наші дослідження, а 
також дослідження науковців В. Білоусової, Н. Зінченко, В. Киричок,: О. Столяренко, Л. Чекараміт, що підтверджуються практикою шкільного виховання, точкою відліку в морально-естетичному вихованні узято категорію «стосунки».

Об'єктами стосунків для людини є речі, процеси, явища, угруповання, люди, сама людина і навколишній світ. Оскільки з усіма цими об' єктами людина пов'язана більшим або меншим їх знанням, переживаннями щодо них, відповідними реакціями поведінки, то зрозуміло, як важливо формувати в особистості ставлення до різних аспектів реальності, що за змістом і формами відповідають загальнолюдським цінностям i нормам гуманістичної моралі.

У багатоманітній системі взаємозв’язків - людина і суспільство, людина і держава, людина i природа тощо- взаємини «людина i людина» посідають чільне місце. С. Рубінштейн зазначав, що будь-яка поведінка людини - бажає вона того чи ні - $€$ виховна поведінка: вона так чи інакше впливає на іншу людину. Поведінка, вчинки однієї (кожної) людини як така, що зумовлює поведінку іншої людини [3].

С. Рубінштейн постійно наголошував на виховному значенні взаємин, їх визначальній ролі в повсякденній життєдіяльності людини. Він писав: «Формування людських стосунків (взаємини людини з іншою людиною) як моральна дуель, боротьба у якій $є$ активне ставлення до іншої. Моє ставлення до іншої людини повинне обеззброїти ії негативні наміри, деморалізувати їх, поставити ії̈ в такі моральні умови, за яких втрачається, негативне ставлення. Відбувається активна перебудова (детермінація) поведінки інших людей, зміна моральних умов їх поведінки на основі мого ставлення до них» [4].

Виняткового значення набувають гуманні стосунки старшокласників в організації учнівського самоврядування. Гуманні взаємини завжди зорієнтовані на ціннісне ставлення до людини: людина - абсолютна цінність, «міра всіх речей» на Життя, гідне Людини. Вони пов'язані з розвитком дитини як особистості, закріпленням у свідомості учня загальнолюдських та естетичних цінностей, емоційно моральних настанов, що регулюють співжиття та стосунки між людьми. У їх основу покладено «золоте правило моральності»: стався до людей так, як ти бажаєш, щоб вони ставилися до тебе.

В узагальненому вигляді такі загальнолюдські цінності, як земля - спільний дім людства, вітчизна - унікальна для кожної людини Батьківщина; мир, злагода між людьми, народами і державами - головна умова існування Землі; загальнолюдська й національна культура - багатство, накопичене людством, необхідні для формування естетичного середовища учнів.

Як морально-естетичне явище (феномен) гуманні взаємовідносини подаються спектром морально-естетичних цінностей, у центрі яких є людська гідність і повага. Отже, усе викладене надає підставу розглядати гуманні взаємини як найважливіший компонент змісту морально-естетичного виховання, що становить його базу.

Цей зміст можна подати так: розуміння і прийняття школярами універсальних загальнолюдських цінностей; осмислення єдності людського роду і себе як неповторної частини; повага до людського життя, усвідомлення його недоторканості; діалог між різними культурами і народами; формування досвіду гуманних взаємин (повага людської гідності, терпимість, людяність, доброта, справедливість, милосердя, вміння пробачати, створювати красу, великодушність, протистояння злу, неприпустимість недовіри і ворожості, доброзичливість); форми їх вираження: тактовність і делікатність; нагромадження досвіду проживання емоційно насичених ситуацій гуманної поведінки (співчуття, співпереживання, вміння радіти за інших); організація учнями актів милосердя, вияв турботи про ближніх і далеких, повага до прав і переваг інших людей, організація виставок, концертів, створення предметів краси, благоустрій приміщень 
тощо; оволодіння ситуацією реальної відповідальності, прийняття рішення, вільного вибору вчинків, способів саморегуляції поведінки в усіх галузях життєдіяльності; засвоєння цінностей національної культури; самовиховання і самооцінювання [1, с. 52].

Основним критерієм гуманного ставлення до людей є доброта. Добро - у межах моральної свідомості - це абсолютна, самоочевидна загальнолюдська цінність, що втілює в собі моральне, людське, символізує щастя і благополуччя людини, із добром пов'язуються всі позитивні відчуття людини, що сприяють іiі життедіяльності і виражають іiі прагнення до своєї досконалості та вдосконалення довкілля, краса, гармонія. Тому добро - це людяність, (гуманність), яка реалізується у справах, вчинках. Лише втілене в благодіяннях, в особистісних якостях (чеснотах) добро може слугувати ознакою гуманної людини. Добра людина - це людина, яка завжди несе благо добро, благополуччя і радість людям, вона завжди доброзичлива. Доброзичливість може виявлятися в умінні підняти настрій, вислухати людину, виявити інтерес до ії турбот, розділити їі горе та радість, вчасно прийти на допомогу всім, хто її потребує [1, с. 54].

Співчуття і чуйність, уважність до людей, бережливе ставлення до їхніх почуттів важливі компоненти доброти, тому добра людина - співчутлива, готова відгукнутися на переживання інших [1, с. 56].

Важливим компонентом гуманних взаємин $є$ здатність відчувати сором, переживати провину. Людині, не здатній до морально-етичних та естетичних переживань, властиве байдуже ставлення до людей, що породжує жорстокість. Почуття сорому, провини, муки сумління виникають тоді, коли людина не шукає виправдання своїм помилкам і прорахункам, проте часто учні не наважуються вголос визнавати своїх помилок, провини за вчинки. Водночас надмірно розвинене почуття сорому може підірвати віру учня у свої можливості й сили. На цьому грунті розвивається невпевненість у собі, яка 3 часом закріплюється у стійкій якості, рисі характеру сором'язливості. На основі розвинених почуттів сорому, провини потім формується совість, що є вищою формою моральної регуляції поведінки [1].

Повага людської гідності, доброта й інші якості гуманних взаємини найчастіше взаємодіють із співчуттям, що $є$ однією 3 фундаментальних якостей людини як суспільної істоти [1, с. 64].

Співчуття виражається насамперед у розумінні почуттів і думок іншої людини, наданні підтримки іiі прагненням і готовності сприяти їх здійсненню. Переживання допомагають людині визначитися у своєму ставленні до вчинків інших людей і власних, творів мистецтва, довкілля. Спонукальна роль переживань, як доведено психологами, виявляється навіть щодо переконань, які стають активною дією лише тоді, коли вони підкріплені переживаннями [1, с. 69]. Виняткове значення при цьому має розвинена здатність до естетичного переживання і співпереживання.

Здатність до співпереживання, співчування (емпатія) передбачає не просто розуміння емоційного стану іншого, а й відтворення його в самому собі. Численними психологічними дослідженнями доведено, що емпатія має різні форми. Так, у формі співпереживання вона може бути пов'язана з егоїстичними мотивами. У цьому разі переживання за іншого грунтуються на потребі лише у власному благополуччі. Співчування $є$ більш складною формою емпатії, оскільки воно грунтується на потребі благополуччя іншого. Найвища форма емпатії - це дієва емпатія, тобто не лише розуміння стану іншого, переживання за нього, розуміння й переживання творів мистецтва й безпосередня діяльність за законами краси. Дієва емпатія повною мірою виражає інтенсифікацію, ототожнення себе з іншою людиною чи твором мистецтва [1, с. 74].

3 емпатією пов'язана чуйність. Вона виявляється в поважному ставленні до інтересів, почуттів і потреб людей, полегшуючи розуміння їх душевного стану i 
настрою, мотивів, якими вони керуються, здійснюючи ті чи ті вчинки. На жаль, як свідчить шкільна практика, 3-поміж старшокласників усе менше тих, хто розуміє потребу чуйності та виявляє іiі в повсякденному житті. Взаємні уподобання їх часто грунтуються на інтересі до моди, безцільному проведенні часу, а не на спільності душевних переживань. Долучення до емоційного стану інших людей поступово виробляє внутрішній такт і культуру співпереживання. Головні ознаки тактовності обережність, почуття міри, вміння знайти в кожному конкретному випадку потрібну форму звернення, вміння бути ненав'язливими у присутності інших, у смаках, бажаннях тощо. Основними іiі виявами є розуміння внутрішнього стану людини, правильне оцінювання своїх слів, вчинків, розуміння того, як їх сприймає інша людина, яку реакцію вони викличуть у неї [1, с. 76].

Спостереження за старшокласниками в різних ситуаціях показали, що для них характерна або повна або часткова відсутність показників тактовності в їхніх взаєминах 3 однокласниками. 3 тактовністю органічно пов'язана делікатність - оптимальна форма вираження гуманності, стрижень і мірило істинної вихованості людини. Щира, непідробна делікатність виявляється в особливо тонкому розумінні людей, у звертанні, чуйному, бережливому ставленні до людини (до мистецтва), прагненні не завдавати їй неприємностей. Діапазон відтінків делікатності дуже широкий - від здатності людини поводитися 3 людьми обережно, не принижувати їхнього самолюбства, тобто глибоко поважати їхні права, людську гідність, до розуміння того, як чинити в конкретній ситуації, як краще виразити співучасть, допомогти, вміти радіти чужому успіху [1, с. 80].

Повага до людини органічно пов'язана 3 наданням їй допомоги. Наші спостереження свідчать, що старшокласники високо цінують допомогу і турботу про інших. У повсякденному житті вони приходять на допомогу один одному, найчастіше у навчанні. Із визнанням людської гідності, повагою до особистості тісно пов' язана така риса гуманного ставлення до людей, як довіра. Довіра передбачає таке ставлення до іншої людини, основою якого $є$ iii віра в добросовісність, чесність і щирість, переконаність у їі правоті, відповідальності та порядності. Вона стимулює людину до шляхетних вчинків, не дозволяє їй чинити аморально, ганьбити свою гідність. У цьому зв'язку важливе завдання педагогічного керівництва - культивування довіри, створення в оточенні старшокласників атмосфери взаємної довіри і доброзичливості.

Умовами довіри між людьми $є$ чесність і правдивість- цінності, у яких виражаються основні норми гуманності й порядності. Старшокласники повинні усвідомлювати, що чесність і правдивість як вимоги й норми життя зумовлюються потребою спільної діяльності людей (у сім’ї, школі, на виробництві тощо). Риса, що характеризує юнацький вік у стосунках з людьми, - це справедливість. Старшокласники надзвичайно чутливі до несправедливості з боку вчителів, батьків, однокласників, проте не завжди вміють бути справедливими самі. Формування почуття справедливості у старшокласників пов'язане 3 розв'язанням питань соціальної справедливості. Почуття справедливості - це визнання обов'язковим для всіх моральних вимог, норм поведінки та повага прав усіх людей. Лише визнаючи права інших, людина активно, вільно виконує свої обов' язки [1, с. 82].

Самооцінка, адекватна гідності, надає змогу правильно визначати життєві цілі, порівнювати свої можливості з вимогами інших, нарівні із совістю та честю $є$ способом усвідомлення своєї відповідальності перед собою як особистістю. Про самооцінку людини - «високу чи низьку» - можна робити висновки згідно з тим, заради чого вона живе [1, с. 83].

Поняття «ціннісне ставлення людини» грунтується на поняттях «цінність», «ціннісна орієнтація» (В. Блюмкін, О. Дробницький, В. Тугарінов та ін.) Цінність $є$ 
складним комплексним утворенням, яке міститься в пізнавальних структурах, процесах соціального життя і культури, світогляді людини, що потрібно враховувати під час організації роботи з морально-естетичного виховання особистості. У теорії цінностей категорія «цінність» визначається як залежна від історичного розвитку, соціальних умов, суспільних відносин, діалектики абсолютного і відносного, об'єктивного й суб' єктивного [1, с. 86].

Аналіз формування естетичного середовища передбачає розгляд етапів розвитку окресленого явища, які $\epsilon$ наслідком його дискретно безперервної природи. Етапи $\epsilon$ відносно завершеними, взаємопов'язаними, взаємозумовленими і характеризуються єдністю мети, специфікою завдань і деякою якісною своєрідністю. Перехід у нову якість визначає межі між етапами [1, с. 114].

Кожна зі стадій формування гуманних взаємин складається 3 персоналізаційного, інтегративного, когнітивного й адаптивного етапів, визначених згідно 3 концепцією відносин В. М'ясищева, О. Бодальова, а також з урахуванням особливостей взаємодії зовнішніх і внугрішніх умов становлення гуманних взаємин у старшому шкільному віці. Педагогічний аспект етапності полягає в диференціації виховної морально-естетичної діяльності залежно від рівня, на якому перебуває позиція особистості вихованця [2, с. 82].

Другий ступінь - конструктивний. У процесі його проходження учень у більшості випадків намагається або утвердитися в системі колективних чи групових стосунків, посісти в них місце, що його задовольняє, або змінити порядок речей, думку про себе i ставлення оточуючих, що його не задовольняють, шляхом нових гуманістичних змін, ціннісного ставлення до однолітків. Ця стадія відрізняється яскравим виявом характеру учня до оточуючого і самого себе. Вона надає педагогові змогу зробити висновки про наявність і особливості кількісних і якісних змін у гуманістичному рівні учня, скоригувати виховний процес відповідно до індивідуальних, особливостей його розвитку тощо [2, с. 82$]$.

Третій ступінь - реалізаційний - характеризується тим, що у процесі становлення і розвитку особистих, партнерських та інших стосунків учні через актуалізацію гуманістичних цінностей ситуативно намагаються застосувати їх у практиці реалізації взаємин, які сприяють їхній самореалізації і самоутвердженню у класі, школі. Характер ставлень до довкілля, до людей у цей час детермінується особливостями ставлення до них значущих для учнів осіб, колективу в цілому. Велику роль тут відіграє прагнення старших школярів самим зрозуміти сутність тієї чи тієї моральної вимоги, тієї чи моральної риси вже на рівні узагальнення, що покладено в основу проективного й корекційного процесів. Цьому сприяє самостійне входження вихованців у дискусії, обговорення морально-естетичних проблем на спеціальних диспутах, різних зборах, конференціях та ін. [2, с. 84].

Четвертий ступінь - продуктивний - відрізняється від усіх інших тим, що учні без зовнішнього впливу встановлюють і реалізують соціально значущі, ціннісні ставлення до колективу, людей і самих себе. Тут яскраво виявляється прагнення вихованця самостійно будувати й коригувати своє ставлення до навколишніх, продуктів краси, піддаючи аналізу цілі, засоби і результати. Однак в окремих випадках такий аналіз не може повноцінно здійснюватися без зовнішнього доведення, оскільки учням складно співвіднести результат ставлення 3 мірою, характером і результатом впливу на його об'єкт-суб' єкт [2, с. 86].

Найважливішою умовою здійснення формування естетичного середовища учнів основної та старшої школи є включення учнів у спеціально організований умовний $\mathrm{i}$ реальний процес реалізації засобів і способів вияву різних за характером взаємин і аналізу результатів впливу на їх об’єкт (суб'єкт). Отже, виокремлюючись із головної 
суперечності, що визначає закономірний зв'язок зовнішніх чинників і внутрішніх умов, решта зводиться до суто внутрішньої рушійної сили розвитку особистості учня суперечність між його морально-етичними потребами, що змінюються у практиці реалізації гуманних взаємин, і реальними можливостями їх задоволення.

Література

1. Білоусова В. О. Теорія та методика гуманізації відносин старшокласників у позаурочній діяльності загальноосвітніх шкіл: [монографія]/ В. О. Білоусова, Л. Г. Коваль. - К. : І3МН, 1997. - 192 с. 2. Битинас Б. П. Структура процесса воспитания: методологический аспект / Б. П. Битинас. - М. : Наука, 1989. - 237 с. 3. Рубинштейн С. Л. Тактика и стратегия этики/ С. Л. Рубинштейн // Вопросы психологии. - 1979. - № 5. - С. 142. 4. Рубинштейн С. Л. Тактика и стратегия этики / С. Л. Рубинштейн // Вопросы психологии. - 1979. - № 6. - С. 150. 